\title{
Notes on a deamination method proposed for determining 'chemically available lysine' of proteins
}

\author{
By R. M. ALLISON*, W. M. LAIRD ANd R. L. M. SYNGE \\ Agricultural Research Council's Food Research Institute, \\ Colney Lane, Norwich NOR $7 \mathrm{OF}$
}

(Received 22 November 197I - Accepted 8 August 1972)

\begin{abstract}
1. Details of a chemical method, using acetic acid and sodium nitrite, for determining 'available lysine' in plant materials are given. An analytical procedure was used which distinguished lysine from ornithine ; the latter was liable to arise in the course of the deamination and hydrolysis procedure.

2. The experimentally determined 'available lysine' contents of various samples of leafprotein concentrates showed significant positive correlations with previously reported values for their biological value and true digestibility. 'Available lysine' correlated significantly with total lysine liberated by direct acid hydrolysis.
\end{abstract}

The method of Carpenter (r960) for determining 'available lysine' (lysine residues having a free $\epsilon-\mathrm{NH}_{2}$ group) has been very successful for assessing the nutritional quality of food proteins of animal origin, but less so for plant proteins. In part, this has been due to destruction of dinitrophenyl groups when the acid hydrolysis is done in the presence of carbohydrates and, in part, to interference by plant pigments. Roach, Sanderson \& Williams ( 1967 ) inverted the procedure, by determining unmodified lysine remaining after dinitrophenylation and hydrolysis, and their method has had considerable success in evaluating plant materials. If we follow this approach, $N$-dinitrophenylation has no special virtue for abolishing the free amino groups of lysine residues, and we thought that the traditional deamination with nitrous acid might have advantages, in that the reagent has a much smaller molecule than fluorodinitrobenzene, and is therefore less likely to suffer steric hindrance. Moreover it acts at a different $\mathrm{pH}$ from that used during dinitrophenylation, and might therefore detect different modes of chemical linkage of the amino groups. Similar reasoning has led other workers to use reaction with acrylonitrile in the presence of triethylamine (Pisano, Finlayson \& Peyton, I969; Harding \& Rogers, I97x) or amidination (e.g. Mourgue, Baret \& Renai, I965; Mauron, I966). (See especially Finot \& Mauron, I972.)

Allison (I97I ; cf. Allison, I970) has described the results of experiments in which we studied leaf-protein concentrates (LPC) of previously established nutritional performance. However, the chemical methods used in this work have not been fully described and further statistical analysis has brought out some new points.

* Present address: Applied Biochemistry Division, Department of Scientific and Industrial Research, Private Bag, Christchurch, New Zealand. 


\section{EXPERIMENTAL}

Before analysis, all LPC samples were finely powdered in a rotary mill (Casella, London; No. ${ }^{3} 8$, fitted with a $2 \cdot 3^{6} \mathrm{mesh} / \mathrm{mm}$ sieve) and weighed out air-dry.

Dry matter was determined by drying to constant weight in an oven at $105^{\circ}$.

Total nitrogen was determined by the semi-micro-Kjeldahl procedure described by Jennings \& Watt (1967).

Hydrolysates were prepared by refluxing about $5 \mathrm{mg}$ of protein, LPC or their deamination products for $18 \mathrm{~h}$ in $4 \mathrm{ml}$ of constant-boiling hydrochloric acid (about $6 \mathrm{M}$, prepared from $\mathrm{AR}$ grade reagent).

Quantitative analyses for basic amino acids were performed on a Beckman-Spinco Model I 2oC Amino Acid Analyzer, using suitable amounts of the hydrolysates. To separate ornithine from lysine, both of which are eluted together on the $50 \mathrm{~mm}$ column recommended for basic amino acids, a $180 \mathrm{~mm}$ column was used and eluted with the recommended $\mathrm{pH} 5 \cdot 25$ buffer at $55^{\circ}$.

\section{Deamination procedure}

This was performed under the conditions of Peters \& Van Slyke (1932). Before the deamination, a sample (about $5 \mathrm{mg}$ ) of the powdered LPC was soaked overnight, at least, in $0.7 \mathrm{ml}$ aqueous acetic acid $(300 \mathrm{ml} / \mathrm{l})$ in a $10 \mathrm{ml}$ stoppered Erlenmeyer flask. The stopper was replaced by a right-angled tubulature through which a piece of polyethylene tubing had been passed, enabling the flask and contents to be purged with White-Spot nitrogen gas (British Oxygen Co. Ltd). After purging with $\mathrm{N}_{2}$ for about Io min, the joint was eased out without removing the polyethylene tubing or interrupting the flow of $\mathrm{N}_{2}$, and $0.2 \mathrm{ml}$ of a sodium nitrite solution ( $800 \mathrm{~g}$ in $\mathrm{I} 1$ water) was added. The reaction was allowed to proceed for $30 \mathrm{~min}$, during which time gentle swirling was applied, but special care was needed to prevent any particles from climbing the walls of the flask. Addition of a drop of octan-2-ol was useful for quelling any frothing during the reaction or the subsequent evaporations. Excess nitrite was removed as quickly as possible by adding $2 \mathrm{ml} 6 \mathrm{M}-\mathrm{HCl}$ and evaporating to dryness under reduced pressure at a temperature below $40^{\circ}$. Three such additions and evaporations were usually necessary.

The method of deamination was first tested by application to crystallized bovine plasma albumin (Armour Corp., Batch no. 2770). Acetylation of the $\epsilon-\mathrm{NH}_{2}$ groups with acetic anhydride and glacial acetic acid (Fraenkel-Conrat, 1957) protected these groups, and complete recovery of lysine was obtained from hydrolysates after deamination of the acetylated albumin. No difficulty was experienced in removing the excess nitrite from this soluble protein, after deamination, by a single evaporation with $6 \mathrm{M}-\mathrm{HCl}$. The necessity for further such treatments was only apparent when hydrolysates of deaminated LPC treated as for plasma albumin showed upon analysis the presence of no amino acids at all. 
Table I. Chemical and nutritional assessments of non-leguminous leaf-protein concentrates $(L P C)$

\begin{tabular}{|c|c|c|c|c|c|c|c|}
\hline & & & $\begin{array}{r}\text { Ifys } \\
\text { (as } \mathrm{g} / \mathrm{kg} \\
\text { origina }\end{array}$ & $\begin{array}{l}\text { ne } N \\
\text { total } N \text { in } \\
\text { sample) }\end{array}$ & Percentage & & \\
\hline LPC sample & $\begin{array}{c}\text { Authors' } \\
\text { reference } \\
\text { no.* }\end{array}$ & $\begin{array}{l}\text { Total N } \\
\text { (g/kg dry } \\
\text { matter) }\end{array}$ & $\begin{array}{c}\text { Untreated } \\
\qquad(a)\end{array}$ & $\begin{array}{c}\text { After } \\
\text { deamination } \\
\text { (b) }\end{array}$ & {$\left[100\left(1-\frac{b}{a}\right)\right]$} & $\begin{array}{c}\text { True } \\
\text { digestibility* }\end{array}$ & $\begin{array}{l}\text { Biological } \\
\text { value* }\end{array}$ \\
\hline Nasturtium & 24 & 106 & 72 & $13 \cdot 8$ & $80 \cdot 8$ & 9ז & 84 \\
\hline Wheat & $\begin{array}{l}12 \\
13 \\
14\end{array}$ & $\begin{array}{l}\text { I } 18 \\
103 \\
104\end{array}$ & $\begin{array}{l}59 \\
63 \\
64\end{array}$ & $\begin{array}{r}\text { II.6 } \\
\text { I } 3 \cdot 4 \\
7 \cdot 7\end{array}$ & $\begin{array}{l}80 \cdot 3 \\
78 \cdot 8 \\
88 \cdot 0\end{array}$ & $\begin{array}{l}83 \\
85 \\
86\end{array}$ & $\begin{array}{l}80 \\
88 \\
91\end{array}$ \\
\hline $\begin{array}{l}\text { Rape } \\
\text { (chloroplasts) }\end{array}$ & $\begin{array}{l}18 \\
20\end{array}$ & $\begin{array}{l}86 \\
84\end{array}$ & $\begin{array}{l}55 \\
48\end{array}$ & $\begin{array}{l}17 \cdot 9 \\
18 \cdot 3\end{array}$ & $\begin{array}{l}67 \cdot 4 \\
6 I \cdot 8\end{array}$ & $\begin{array}{l}67 \\
75\end{array}$ & $\begin{array}{l}71 \\
80\end{array}$ \\
\hline $\begin{array}{l}\text { Rape } \\
\text { (cytoplasm) }\end{array}$ & $\begin{array}{l}18 \\
20\end{array}$ & $\begin{array}{l}125 \\
131\end{array}$ & $\begin{array}{l}68 \\
62\end{array}$ & $\begin{array}{r}10 \cdot 1 \\
8 \cdot 2\end{array}$ & $\begin{array}{l}85 \cdot 1 \\
86 \cdot 7\end{array}$ & $\begin{array}{l}96 \\
94\end{array}$ & $\begin{array}{l}87 \\
91\end{array}$ \\
\hline
\end{tabular}

\section{RESULTS AND DISCUSSION}

Available lysine $\mathrm{N}$ as a percentage of total $\mathrm{N}$ was calculated from the analytical results as follows:

$a=$ lysine $\mathrm{N}$ in hydrolysate of original sample expressed as $\mathrm{g} / \mathrm{kg}$ of total $\mathrm{N}$;

$b=$ lysine $\mathrm{N}$ in deaminated sample expressed as $\mathrm{g} / \mathrm{kg}$ of total $\mathrm{N}$ of sample before deamination ('unavailable lysine');

$a-b=$ available lysine $\mathrm{N}$ expressed as $\mathrm{g} / \mathrm{kg}$ of total $\mathrm{N}$ in original sample.

Thus, $\mathrm{I} 00\left(\mathrm{I}-\frac{b}{a}\right)=$ percentage availability of lysine.

Table I gives the results for eight samples of LPC from non-leguminous plants as an example of the results obtained by this procedure. The true digestibility and biological value of these materials had previously been determined by Henry \& Ford (1965) and these indices of nutritional value are also given in Table $\mathbf{I}$.

Table 2 gives statistical analyses of these and the other results reported by Allison (I97I). These results show that a good measure of agreement was obtained between the experimentally determined 'available lysine' contents of the LPC and their true digestibilities. The further correlation between biological value and digestibility is interesting, and indicates that the amino acids that were absorbed from the less digestible LPC were poorly retained within the body. This could imply that the different qualities of LPC yielded different patterns of available amino acids upon digestion. Certainly, the observed correlation between 'available lysine' content and biological value indicates loss of availability of amino acids in addition to lysine, since in fact methionine is the first limiting amino acid in LPC (cf. Vithayathil \& Murthy, 1972; Bosshard, I972). 
Table 2. Statistical assessment of the results of Allison's (1971) analyses of leaf-protein concentrates. Biological value and true digestibility are from Henry $\mathscr{F}^{\circ}$ Ford (1965)

\begin{tabular}{|c|c|c|c|c|}
\hline \multirow[b]{2}{*}{ Correlation } & \multicolumn{3}{|c|}{ Correlation coefficient } & \multirow{2}{*}{$\begin{array}{l}\text { No. of } \\
\text { samples }\end{array}$} \\
\hline & Legumes & Non-legumes $\ddagger$ & All samples & \\
\hline Biological value with true digestibility & $+0.269+\mathrm{NS}$ & $+0.829^{*}$ & $+0.612 \dagger^{*}$ & 15 \\
\hline $\begin{array}{l}\text { Percentage availability of lysine with: } \\
\text { biological value } \\
\text { true digestibility } \\
\text { lysine } \mathrm{N} \text { (as g/kg total } \mathrm{N} \text { ) }\end{array}$ & $\begin{array}{l}+0.317+\text { NS } \\
+0.85^{*} \\
+0.63^{*}\end{array}$ & $\begin{array}{l}+0.784^{*} \\
+0.835^{* *} \\
+0.788 * *\end{array}$ & $\begin{array}{c}-\overline{-} \\
+0.747^{* *} \\
+0.676^{* *}\end{array}$ & $\begin{array}{l}15 \\
15 \\
23\end{array}$ \\
\hline
\end{tabular}

NS, not significant.

Statistical significance: ${ }^{*} P \leqslant 0.05 ; * * P \leqslant 0.01$.

$\dagger$ Excluding results for sweet clover.

f See Table 1 .

It is now well known that reducing sugars condense with lysine $\epsilon-\mathrm{NH}_{2}$ groups to give products from which lysine is released only in poor yield under the conditions of acid hydrolysis. Indeed, some of the acid-stable coupling products have been identified (for review, see Mauron, 1970). During preparation of LPC, reaction of amino groups with quinones formed by enzymic or spontaneous oxidation of plant $o$-diphenols is also liable to occur, probably to a greater extent. Possible nutritional effects of such reactions have been largely ignored (but see Horigome \& Kandatsu, I 968). Experiments on the behaviour during acid hydrolysis of the coupling products of amino acid derivatives with quinones (Cranwell \& Haworth, I97I) and humic acids (Perry \& Adams, I97I) show quite clearly that an amino acid residue whose amino group has become involved in such a linkage is released only in part under the usual conditions of acid hydrolysis of proteins. The positive correlation of 'available lysine' with ' total lysine' found by us (Table 2 ) is thus what would be expected if compounds of this kind involving lysine amino groups are undergoing only imperfect hydrolysis. Similar chemical reactions have been postulated as leading to the incorporation of proteins and amino acids into the organic matter of soil (for a review, see Pierpoint, 1970). We hope that the method here described may prove useful with such humic materials for study of the extent and nature of chemical combination of their amino groups.

A zone in the position of ornithine occurred during amino acid analysis of hydrolysates of deaminated LPC and calls for comment. No such zone was found in the hydrolysates of undeaminated LPC. Although it has been claimed (Gallup \& Schmidt, I930; Bertho \& Grassmann, I938) that the guanidine group of arginine reacts slowly with nitrous acid, any ornithine residues arising thus would be deaminated and would not appear in the final analysis. It seems more likely that the side-chains of arginine or citrulline residues in the LPC undergo some other reaction in the presence of nitrous acid and that the resulting product yields ornithine during the heating with hydrochloric acid. The only relevant experiments of which we are aware are those of Gornall \& Hunter (1940), who showed that $N$-carbamoyl amino acids (including citrulline) 
react slowly with nitrous acid to give up $0 \cdot 6-2$ atoms N/ureido group in the course of 2. $5 \mathrm{~h}$ under the conditions of Peters \& Van Slyke (1932). (See also Mirvish, 197I.)

We thank Miss Marjorie Byers, Mr N. W. Pirie and Dr A. A. Woodham for gifts of LPC samples and for helpful discussions. We have also been helped by discussions with Drs K. J. Carpenter, J. E. Ford, C. H. Lea, N. A. Matheson, J. W. G. Porter and David S. Robinson. We are grateful to Mrs Julia Levett for the amino acid analyses, to Miss Janice Payne for other technical help, and to the Statistics Departments of Lincoln College and Rothamsted Experimental Station for the statistical analyses of the results.

R. M. A. acknowledges a grant from the Underwood Fund of the Agricultural Research Council.

\section{REFERENCES}

Allison, R. M. (1970) $\mathfrak{7 l}$ N.Z. Inst. Chem. 34, 127.

Allison, R. M. (197I). In Leaf Protein: Its Agronomy, Preparation, Quality and Use p. 78 [N. W. Pirie, editor]. I.B.P. Handbook No. 20. Oxford: Blackwell Scientific Publications Ltd.

Bertho, A. \& Grassmann, W. (1938). Laboratory Methods of Biochemistry p. 59 [W. McCartney, translator]. London: Macmillan.

Bosshard, H. (1972). Helv. chim. Acta 55, 32.

Carpenter, K. J. (1960). Biochem. F. 77, 604.

Cranwell, P. A. \& Haworth, R. D. (1971). Tetrahedron 27, 1831 .

Finot, P. A. \& Mauron, J. (1972). Helv. chim. Acta 55, 1153.

Fraenkel-Conrat, H. (1957). Meth. Enzym. 4, 247.

Gallup, W. D. \& Schmidt, C. L. A. (1930). Univ. Calif. Publs Physiol. 7, 201 .

Gornall, A. G. \& Hunter, A. (1 940). Biochem. F. 34, I92.

Harding, H. W. J. \& Rogers, G. E. (197I). Biochemistry, N.Y. 10, 624.

Henry, K. M. \& Ford, J. E. (1965). F. Sci. Fd Agric. 16, 425.

Horigome, T. \& Kandatsu, M. (1968). Agric. biol. Chem. F. 32, I093.

Jennings, A. C. \& Watt, W. B. (1967). F. Sci. Fd Agric. 18, 527.

Mauron, J. (1966). Int. Z. VitamForsch. 36, 362.

Mauron, J. (1970). Int. Z. VitamForsch. 40, 209.

Mirvish, S. S. (1971). F. natn. Cancer Inst. 46, $118_{3}$.

Mourgue, M., Baret, R. \& Renai, J. (1965). Annls pharm. fr. 23, 48 I.

Perry, D. R. \& Adams, W. A. (197I). Biochem. F. 125, 29 P.

Peters, J. P. \& Van Slyke, D. D. (1932). Quantitative Clinical Chemistry Vol. 2, Methods p. $38_{5}$. London: Baillière, Tindall \& Cox.

Pierpoint, W. S. (1970). Rep. Rothamsted exp. Stn Part 2, p. 199.

Pisano, J. J., Finlayson, J. S. \& Peyton, M. P. (х 969). Biochemistry, N. Y. 8, 87 I.

Roach, A. G., Sanderson, P. \& Williams, D. R. (1967). Y. Sci. Fd Agric. 18, 274.

Vithayathil, P. J. \& Murthy, G. S. (1972). Nature, New Biology 236, Iо I. 